\title{
Migration of Rod into Retroperitoneal Region: A Case Report and Review of the Literature
}

\author{
Yaşar Bayri ${ }^{2}$, Murat Sakir Eksi ${ }^{1}$, Ramazan Doğrul ${ }^{2}$, Demet Yalçinkaya Koç ${ }^{3}$, Deniz Konya ${ }^{4}$ \\ ${ }^{l}$ Neurosurgeon, Department of Orthopaedic Surgery, UCSF Spine Unit, CA, USA, ${ }^{2}$ Marmara University Medical School and \\ Marmara University Neurological Sciences Institute, Istanbul, Turkey, ${ }^{3}$ Department of Anesthesiology, Marmara University \\ Health Sciences Institute, Istanbul, Turkey, ${ }^{4}$ Department of Neurosurgery, Bahçeşehir University Medical School, Istanbul, Turkey
}

Spinal stabilization with fusion is the widely used method for traumatic or pathologic fracture of spine, spinal stenosis, and spondylolisthesis. Complications may emerge during or after the operations. Infection, hematoma and neurological deficits are early noticed findings. Screw and/or rod fractures present in long-term after surgery. Rod migration in out of the spinal column is a rare entity. A 67-year-old woman was visited our clinic for right leg pain. She had a previous spinal instrumentation surgery for spondylolisthesis in another center 6 years before. After radiological work-up, a distally migrated rod piece was observed in the retroperitoneal portion. The patient was operated for degenerative change; old instruments were replaced and extended to the L2 level with posterior spinal fusion. After the operation, her right leg pain improved. The asymptomatic migrated rod piece has regularly been followed clinically and radiologically, since then. Although it has rarely been reported, migration of the instrumentation material should be kept in mind. Spinal fixation without fusion makes the mechanical system vulnerable to motion effects of spine, especially in a degenerative and osteoporotic background. Long-term, even life-long follow-up is necessary for late term complications.

Key Words: Spinal instrumentation $\cdot$ Migration $\cdot$ Spondylolisthesis $\cdot$ Lumbar spine

\section{INTRODUCTION}

Spinal stabilization with instrumentation is a widely used method for spinal traumas, degenerative spinal disease, and sometimes at congenital spinal malformations. Complications may occur perioperatively or after surgery, such as soft tissue injuries, neurological deficits, acute respiratory failure, hematomas, infections, failure of fusion, breakage or dislodgement of screw or rod ${ }^{1,4,8,10)}$. Even rod migration through the spinal column may occur ${ }^{8)}$. We are describing a case of migrated rod to the retroperitoneal area proven with radiological imaging modalities. In the literature, a few cases of distal migration of rod have been reported (Table 1$)^{1-9,11,12)}$.

\footnotetext{
- Received: June 5, 2014 • Revised: July 2, 2014

- Accepted: August 19, 2014

Corresponding Author: Murat Sakir Eksi, MD

University of California-San Francisco, Spine Unit, 500 Parnassus Avenue MU320 West, San Francisco, CA 94143-0728, USA

Tel: + 1 (415) 4761167, Fax: + 1 (415) 4761304

E-mail: EksiM@orthosurg.ucsf.edu/muratsakireksi@gmail.com

*The authors report no conflict of interest concerning the materials or methods used in this study or the findings specified in this paper. ®This is an Open Access article distributed under the terms of the Creative Commons Attribution Non-Commercial License (http://creativecommons.org/ licenses/by-nc/3.0/) which permits unrestricted non-commercial use, distribution, and reproduction in any medium, provided the original work is properly cited.
}

\section{CASE REPORT}

A 67-year-old woman visited our outpatient clinic in September 2012 with right leg pain persisting for 3 months. She had been operated in another center in 2006 for degenerative lumbar spondylolisthesis. There was no history of trauma or vascular pathology. She was on carbamazepine for trigeminal neuralgia. Her laboratory test results were normal. Physical examination was within normal limits. There was right leg weakness, motor strength of the right lower extremity muscles was as follows: iliopsoas: $3 / 5$, gluteus maximus: $5 / 5$, hamstrings $5 / 5$, quadriceps femoris: $4 / 5$, anterior tibialis: $4 / 5$, extensor hallucis longus: $4 / 5$, extensor digitorum longus: $4 / 5$, gastrocnemius: $5 / 5$, soleus: $5 / 5$, posterior tibialis: $5 / 5$. On the left side; anterior tibialis, extensor hallucis longus and extensor digitorum longus had a motor deficit of $1 / 5$ : the other muscle groups were normal in strength. Deep tendon reflexes were normoactive. Also, there was bilateral neurogenic intermittent claudication. On EMG, there were acute right L2, L3 radiculopathic, and chronic bilateral L5-S1 neuropathic findings.

On 2-plane lumbosacral radiography, bilateral transpedicular screws were observed at L5 and S1 vertebral segments. On lateral lumbar X-ray, a linear hyperdense mass, corresponding 
Table 1. Spinal instrumentation cases with distant rod migration in the literature

\begin{tabular}{|c|c|c|c|c|c|c|c|c|}
\hline $\begin{array}{l}\text { Author }(\mathrm{s}) \text { and } \\
\text { year }\end{array}$ & $\begin{array}{l}\text { Patient age } \\
\text { (years)/ } \\
\text { gender }\end{array}$ & Presentation & $\begin{array}{l}\text { Instrumen- } \\
\text { tation } \\
\text { levels }\end{array}$ & $\begin{array}{l}\text { Location of } \\
\text { migrated rod } \\
\text { piece }\end{array}$ & $\begin{array}{l}\text { Type of } \\
\text { instrumentation }\end{array}$ & $\begin{array}{l}\text { Previous reason for } \\
\text { instrumentation }\end{array}$ & $\begin{array}{l}\text { Time passed } \\
\text { after primary } \\
\text { instrumenta- } \\
\text { tion }\end{array}$ & Treatment \\
\hline $\begin{array}{l}\text { Yablon et al. } \\
\text { (1993) }\end{array}$ & $18 /$ male & $\begin{array}{l}\text { Progressive neck pain } \\
\text { and dizziness }\end{array}$ & C4-C5 & $\begin{array}{l}\text { Posterior cranial } \\
\text { fossa }\end{array}$ & Harrington rod & $\begin{array}{l}\text { Traumatic C4 facet } \\
\text { junp on C5 and } \\
\text { C5 lamina fracture }\end{array}$ & 4 years & $\begin{array}{l}\text { Removal of migrated rod } \\
\text { and all hardware }\end{array}$ \\
\hline $\begin{array}{l}\text { Al-Binali et al. } \\
\text { (2001) }\end{array}$ & $17 /$ male & $\begin{array}{l}\text { Acute lower } \\
\text { gastro-intestinal } \\
\text { bleeding }\end{array}$ & T2-pelvis & Rectum & $\begin{array}{l}\text { Luque-Galveston } \\
\text { posterior } \\
\text { instrumentation }\end{array}$ & $\begin{array}{l}\text { Scoliosis due to } \\
\text { spinal muscular } \\
\text { atrophy }\end{array}$ & 6 years & $\begin{array}{l}\text { Migrated piece removal } \\
\text { through laparotomy and } \\
\text { instrumentation removal } \\
\text { in another surgery }\end{array}$ \\
\hline $\begin{array}{l}\text { Banit et al. } \\
\text { (2001) }\end{array}$ & 10/female & Pain & T9-sacrum & Acetabulum & $\begin{array}{l}\text { Galveston } \\
\text { construct }\end{array}$ & $\begin{array}{l}\text { Scoliosis due to } \\
\text { lumbar } \\
\text { myelomeningocele }\end{array}$ & N/A & $\begin{array}{l}\text { Removal of } \\
\text { instrumentation }\end{array}$ \\
\hline $\begin{array}{l}\text { Habal et al. } \\
(2005)\end{array}$ & $50 /$ male & $\begin{array}{l}\text { Stabbing pain over left } \\
\text { thoracic aperture }\end{array}$ & T12-L2 & Pleural cavity & $\begin{array}{l}\text { Anterior and } \\
\text { posterior } \\
\text { instrumentation }\end{array}$ & $\begin{array}{l}\text { Traumatic L1 burst } \\
\text { fracture }\end{array}$ & 3 months & $\begin{array}{l}\text { Removal with } \\
\text { videothoracoscopy }\end{array}$ \\
\hline $\begin{array}{l}\text { Hirano et al. } \\
(2007)\end{array}$ & 30/female & $\begin{array}{l}\text { Backache worsened } \\
\text { with pregnancy }\end{array}$ & T2-L2 & Pelvis & $\begin{array}{l}\text { Luque rod and } \\
\text { sublaminar wire }\end{array}$ & $\begin{array}{l}\text { Traumatic T8-9 } \\
\text { vertebral fractures }\end{array}$ & 10 years & $\begin{array}{l}\text { Removal through rectal } \\
\text { wall }\end{array}$ \\
\hline $\begin{array}{l}\text { Fitchett et al. } \\
(2008)\end{array}$ & 40/female & $\begin{array}{l}\text { Sharp aching pain with } \\
\text { a hard lump in right } \\
\text { iliac fossa }\end{array}$ & N/A & Iliac fossa & Harrington rod & $\begin{array}{l}\text { Scoliosis due to } \\
\text { trauma }\end{array}$ & 10 years & Removal from abdomen \\
\hline $\begin{array}{l}\text { Wood et al. } \\
\text { (2009)-3 cases }\end{array}$ & 28/female & $\begin{array}{l}\text { Left thigh pain and } \\
\text { tenderness }\end{array}$ & T11-L3 & Thigh & $\begin{array}{l}\text { Anterior } \\
\text { instrumentation }\end{array}$ & Scoliosis & 13 years & Removal from thigh \\
\hline $\begin{array}{l}\text { Chun et al. } \\
\text { (2010) }\end{array}$ & $23 /$ male & $\begin{array}{l}\text { Mild occipital headache } \\
\text { and dizziness }\end{array}$ & $\mathrm{Cl}-\mathrm{C} 2$ & $\begin{array}{l}\text { Posterior cranial } \\
\text { fossa }\end{array}$ & $\begin{array}{l}\text { C1 lateral mass, } \\
\text { C2 pedicle } \\
\text { fixation with } \\
\text { sublaminar wire }\end{array}$ & $\begin{array}{l}\text { Traumatic type } 2 \\
\text { odontoid process } \\
\text { fracture }\end{array}$ & 20 months & $\begin{array}{l}\text { Patient refused operation } \\
\text { for removal }\end{array}$ \\
\hline \multirow[t]{3}{*}{$\begin{array}{l}\text { Dhatt et al. } \\
\text { (2010) }\end{array}$} & $38 / \mathrm{male}$ & $\begin{array}{l}\text { Pain, swelling, and } \\
\text { restriction of movement } \\
\text { of left knee joint }\end{array}$ & T12, L2 & Knee joint & $\begin{array}{l}\text { Anterior } \\
\text { instrumentation }\end{array}$ & $\begin{array}{l}\text { Traumatic L1 } \\
\text { vertebral fracture }\end{array}$ & 4 years & Removal from knee joint \\
\hline & 24/female & $\begin{array}{l}\text { Painful, prominent } \\
\text { nodule in left leg }\end{array}$ & T12-L3 & Calf & $\begin{array}{l}\text { Isola anterior } \\
\text { instrumentation }\end{array}$ & Scoliosis & 8 years & Removal from calf \\
\hline & $21 / \mathrm{male}$ & $\begin{array}{l}\text { Detected on routine } \\
\text { control }\end{array}$ & T12-L3 & Iliopsoas muscle & $\begin{array}{l}\text { Kaneda anterior } \\
\text { instrumentation }\end{array}$ & Scoliosis & 4 years & $\begin{array}{l}\text { Follow-up due to } \\
\text { asymptomatic case }\end{array}$ \\
\hline $\begin{array}{l}\text { lacoangeli et al. } \\
\text { (2012) }\end{array}$ & 69/female & Left S1 radiculopathy & $\mathrm{L} 2, \mathrm{~L} 4$ & $\begin{array}{l}\text { Left rod in the } \\
\text { pre-sacral area, } \\
\text { right rod at the } \\
\text { upper level of } \\
\text { L2 vertebral } \\
\text { body }\end{array}$ & $\begin{array}{l}\text { CD posterior } \\
\text { instrumentation }\end{array}$ & $\begin{array}{l}\text { Pathological L3 } \\
\text { vertebral fracture } \\
\text { due to primary } \\
\text { bone lymphoma }\end{array}$ & 6 years & $\begin{array}{l}\text { Replacement of } \\
\text { instrumentation with L3 } \\
\text { vertebroplasty }\end{array}$ \\
\hline $\begin{array}{l}\text { Lark et al. } \\
(2013)\end{array}$ & 50/female & $\begin{array}{l}\text { Progressive lower } \\
\text { extremity numbness }\end{array}$ & N/A & $\begin{array}{l}\text { Intraperitoneala- } \\
\text { rea penetrating } \\
\text { the colon }\end{array}$ & Harraington rod & $\begin{array}{l}\text { Scoliosis due to } \\
\text { polio }\end{array}$ & 35 years & $\begin{array}{l}\text { Via colonoscopy } \\
\text { extruded rod piece taken } \\
\text { out en bloc }\end{array}$ \\
\hline $\begin{array}{l}\text { Ilbay et al. } \\
(2014)\end{array}$ & 73/female & Low back pain & L4-L5 & $\begin{array}{l}\text { Posterior sacral } \\
\text { area }\end{array}$ & $\begin{array}{l}\text { CD posterior } \\
\text { instrumentation }\end{array}$ & Spondylolisthesis & 4 years & Follow-up \\
\hline Present case & $67 /$ female & Right leg pain & L5-S1 & $\begin{array}{l}\text { Retroperitoneal } \\
\text { region }\end{array}$ & $\begin{array}{l}C D \text { posterior } \\
\text { instrumentation }\end{array}$ & Spondylolisthesis & 6 years & $\begin{array}{l}\text { Replacement with a new } \\
\text { system and follow-up of } \\
\text { asymptomatic migrated } \\
\text { rod fragment }\end{array}$ \\
\hline
\end{tabular}

N/A: Not available, C: Cervical vertebra, T: Thoracic vertebra, L: Lumbar vertebra

to a rod piece was lying in front of the vertebral column (Fig. 1A, C). On axial-plane lumbar computed tomography (CT) imaging, the hyperdense foreign body was present between the lower pole of the right kidney and right iliopsoas muscle (Fig. 2C-E). Also, the rod piece on the right side was missing in the screw heads. No fusion mass was observed in the treated segments. On T2-weighted magnetic resonance imaging (MRI), there was L5-S1 spondylolisthesis and intervertebral disc bulging at L2-3 and L3-4 segments. On axial and coronal images, a hypointense linear mass was observed in the same location as in the CT (Fig. 2A, B and Fig. 3). The patient had a previous lumbar A-P/lateral roentgenogram showing the migrated rod in the same location as in the new films (not shown). In the operation, total laminectomies were performed between $\mathrm{L} 3$ and $\mathrm{L} 5$ vertebrae. The old instrumentation system was replaced with the new one, from L2 to S1; decorticated bone auto-graft was used as fusion mass bilaterally (Fig. 1B, D). The migrated rod piece was present in front of the psoas 

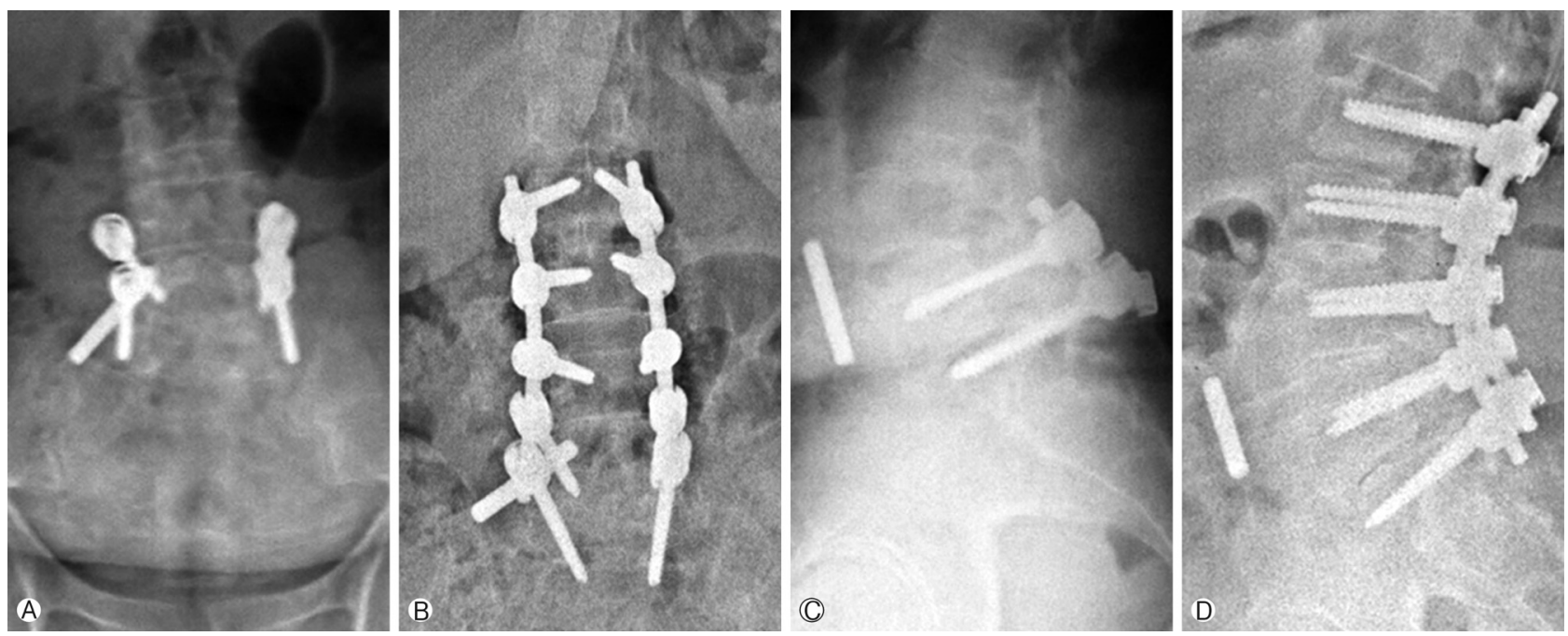

Fig. 1. Pre-operative and post-operative lumbar A-P (A, B) and lateral (C, D) plain radiographies.
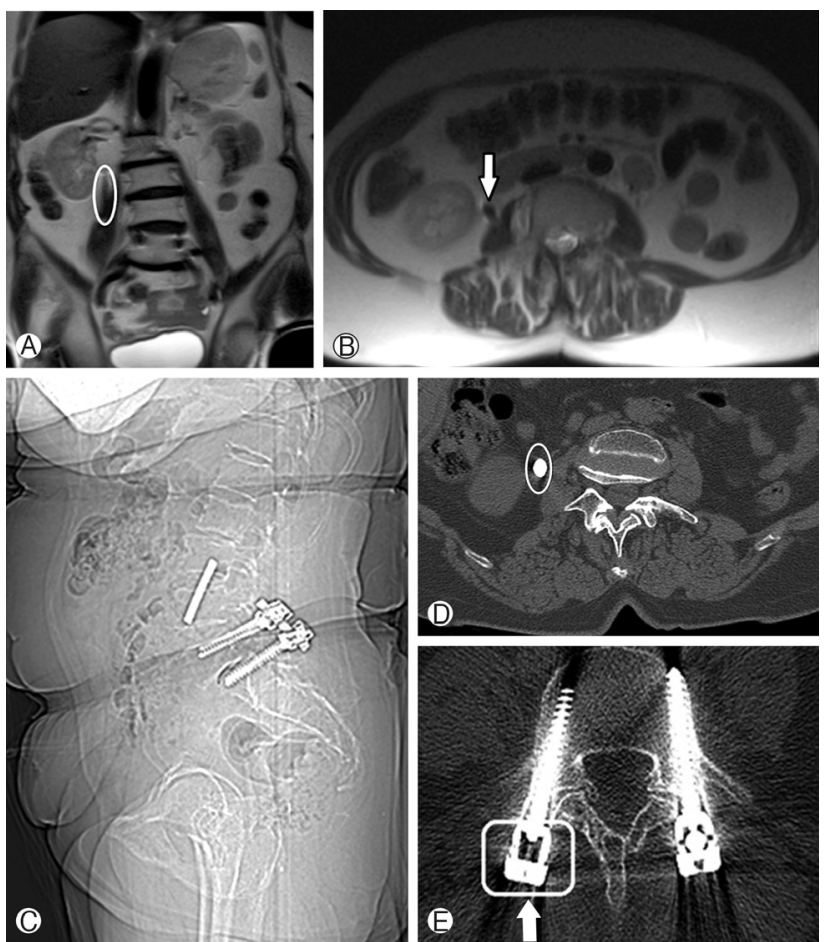

Fig. 2. Migrated rod piece has a lower signal intensity and is present near the right kidney on MRI (small white arrow) (A, B). Appearance of hyperdense rod fragment in abdominal CT with missing rod piece in right screw head (big white arrow) (C-E).

major muscle. To extract the rod piece, an additional anterior approach was necessary. After the operation, the patient's symptoms related to spinal stenosis diminished. There were no symptoms for the migrated rod piece. The rod piece had been in the same location for 3 years. We put her on regular clinical
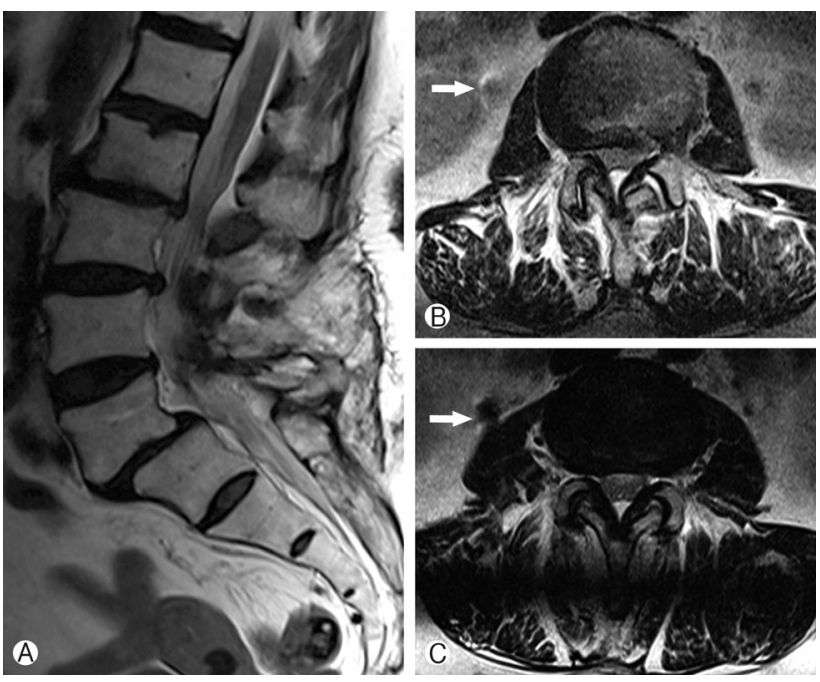

Fig. 3. Lumbar T2-weighted MRI shows L5-S1 spondylolithesis and intervertebral disc bulging at L2-3 and L3-4 segments (A) with hypointense migrated rod piece (white arrows) $(B, C)$.

and radiological follow-ups. At her $12^{\text {th }}$ month follow-up period, she did not have any spinal complaints; she was asymptomatic for the migrated rod piece and her X-rays showed fusion of the lumbosacral spine.

\section{DISCUSSION}

Spinal instrumentation is used to correct spondylotic process and spinal instability secondary to degenerative, traumatic, idiopathic or congenital processes. Acute and late complications may present after spinal stabilization procedures. In long 
term, broken instrumentations are mostly noticed if fusion does not occur at the surgical sites. Rod fracture incidence is between 2 and $11 \%{ }^{4}$. Its migration out of spinal column is extremely uncommon ${ }^{4,8)}$. When this occurs, it may result in catastrophic outcomes such as visceral and vascular injury"). Al-Binali et al. ${ }^{1)}$ reported a spinal instrumented case with acute lower gastrointestinal bleeding. The rod had migrated through the iliac wing into the pelvis and caused internal iliac artery laceration. In another case reported by Fitchett et al. ${ }^{5)}$ a patient, admitted with acute abdominal pain, was detected to have a painful mass in the right iliac fossa. Harrington rod piece was taken out through an abdominal incision. Distal rod migration to the posterior cranial fossa, lung pleura, and leg has also been notified in the literature ${ }^{3,4,6,11)}$. Sometimes, patients did not have any symptoms and they were diagnosed during their routine clinical controls or they presented with symptoms related to instability due to ineffective arthrodesis like in our case ${ }^{3,8,11)}$. Table 1 presents in detail, distally migrated rod cases with clinical presentations, treatment approaches and instrumentation types used in their previous surgery. Our case was totally asymptomatic for the migrated rod piece.

Improperly tightened screws may loosen and rod may slip from its place with gravity and movements of the body. In our case, the screw heads were very tight. However, fusion mass was not observed in the treated segments. Thus, the rod might have moved due to unbalanced motion at instrumented levels without any fusion ${ }^{3,8,11)}$. This may have led to fatigue of the instrumentation with mobile segments and then may have freed rod piece. The rod fragment might have moved through the iliopsoas muscle, again with the help of body movements. The migrated fragment was in the retroperitoneum near the right kidney. Dhatt et al. proposed that proper spinal fixation with dual rods would compensate rotational, bending and extending forces of the body ${ }^{4)}$. In our case, the rod got loosened and migrated out of spinal column despite dual rod system.

Approximately half of migrated rod cases in the literature had remained asymptomatic ${ }^{4}$. Some authors preferred followup instead of removal of the rod fragment ${ }^{11)}$. In our case, our patient's main complaint was related with spinal stenosis with inadequate previous spinal fusion. We first aimed to decompress the stenotic segments, relieve the nerve roots. For this purpose we used a posterior approach. After revision surgery, patient's symptoms regressed. The migrated rod piece was not broken and did not have sharp ends, which could have more devastating results. Also, it had remained in the same location for 3 years. During this time period, fibrosis may have occurred around the migrated rod piece and would cause vascular injury while taking out it. So, we put her on regular clinical follow-ups. Thus, close follow-up of our patient will continue even if she is symptom-free.

\section{CONCLUSION}

Spinal instrumentation with fusion is a very useful technique for spinal column stability. This case showed us that spinal fixation without fusion makes the mechanical system vulnerable to motion effects of spine, especially in a degenerative and osteoporotic background. Although it has been rarely reported, migration of the instrumentation material should be kept in mind. Long-term, even life-long follow-up, is necessary for late complications, if there is no fusion. In a case with distant migration of instruments, surgery for instrument removal should be considered if the patient is symptomatic.

\section{REFERENCES}

1. Al-Binali AM, Sigalet D, Goldstein S, Al-Garni A, Robertson M: Acute lower gastrointestinal bleeding as a late complication of spinal instrumentation. J Pediatr Surg 36:498-500, 2001

2. Banit DM, Iwinski HJ, Jr., Talwalkar V, Johnson M: Posterior spinal fusion in paralytic scoliosis and myelomeningocele. $\mathrm{J}$ Pediatr Orthop 21:117-125, 2001

3. Chun HJ, Bak KH, Kang TH, Yi HJ: Rod migration into the posterior fossa after harms operation: case report and review of literatures. J Korean Neurosurg Soc 47:221-223, 2010

4. Dhatt S, Kumar S, Arora N, Dhillon M, Tripathy SK: Migration of anterior spinal rod from the dorsolumbar spine to the knee: an unusual complication of spinal instrumentation. Spine (Phila Pa 1976) 35:E270-272, 2010

5. Fitchett J, Williams GL, McKain ES, Stephenson BM: A hard object in the right iliac fossa. Ann R Coll Surg Engl 90:W10-11, 2008

6. Habal P, Malek V, Novotny J: Case: unusual migration of osteosynthetic material. Acta Medica (Hradec Kralove) 48:49-52, 2005

7. Hirano K, Deguchi M, Kanamono T: The migration of a broken luque rod: a case report. J Spinal Disord Tech 20:176-179, 2007

8. Iacoangeli M, Di Rienzo A, Nocchi N, Alvaro L, Gladi M, Colasanti R, et al: An unusual instrumentation-related s1 radiculopathy in a patient treated for a primary vertebral (13) lymphoma. Clin Med Insights Oncol 6:375-380, 2012

9. Ilbay K, Yasa N, Ilbay G, Etus V: Migration of a Lumbar Rod to Posterior Sacral Region: An Extremely Unusual Complication of Spinal Instrumentation. Journal of Neurological SciencesTurkish 31:209-212, 2014

10. Slone RM, MacMillan M, Montgomery WJ: Spinal fixation. Part 3. Complications of spinal instrumentation. Radiographics 13:797-816, 1993

11. Wood KE, Fitch RD, Burton DC, Keiger CJ: Anterior scoliosis rod migration to the lower extremity. Spine J 9:e9-12, 2009

12. Yablon IG, Cowan S, Mortara R: The migration of a Harrington rod after cervical fusion. Spine (Phila Pa 1976) 18:356-358, 1993 